\title{
Assisted Reproduction and Cross-Border Maternal Surrogacy Regulations in Selected Nations
}

\author{
Raywat Deonandan $^{1^{\star}}$ and Andreea Bente ${ }^{1}$ \\ ${ }^{1}$ Interdisciplinary School of Health Sciences, University of Ottawa, Ottawa, Ontario, Canada.
}

Authors' contributions

This work was carried out in collaboration between both authors. Author AB performed the literature search, created the tables, and summarized findings. Author RD conceptualized the study and wrote the majority of the text. Both authors read and approved the final

manuscript.

Research Article

Received 31 ${ }^{\text {st }}$ December 2012

Accepted $7^{\text {th }}$ August 2013

Published $14^{\text {th }}$ September 2013

\section{ABSTRACT}

Aims: To ascertain the laws and policies of selected high income countries, with respect to the disposition of their citizens seeking assisted reproductive technologies (ARTs) internationally.

Study Design: Literature review.

Methodology: PubMed, Scopus and Google of various ART terms with terms relating to regulations in the selected nations of Australia, Canada, New Zealand, the UK, the USA, and Israel.

Results: All nations except the USA have a federal ART regulatory presence, distinguish between gestational and traditional surrogacy, and between paid and unpaid surrogacy. Policies concerning the repatriation of children produced by ART abroad vary widely.

Conclusions: Heterogeneous regulations are one of the drivers of the global reproductive tourism industry. Domestic regulations are likely affected by both the values of a specific population and the needs of the industry.

Keywords: ART; IVF; law; reproductive tourism; adoption; repatriation; PGD; surrogacy. 


\section{INTRODUCTION}

Reproductive tourism is one of the 21 st century most surprising and accelerating manifestations of the collision between medicine and commerce. Defined as "the travelling of [clients] from their country of residence to another country in order to receive a specific treatment or to exercise personal reproductive choice" [1], it is characterized by the seeking of one or more of the panoply of assisted reproductive technologies (ARTs), including in vitro fertilisation (IVF), intracytoplasmic sperm injection (ICS), preimplantation genetic diagnosis (PGD), gamete donation and maternal surrogacy. Globally, the industry is thought to be worth billions of dollars annually [2].

While the patterns and demographics of this service seeking behaviour are largely unknown, it is thought that India is emerging as the world leader of ART service provision, particularly with respect to maternal surrogacy, due in large part to India's very large number of clinics marketing services to foreign clientele [3]. That country's ART industry is likely worth $\$ 500$ million [4] to $\$ 2.3$ billion; [2] and its provision of cross-border services plays a strong part in that revenue, judging from the extent to which Indian clinics overtly market to foreign clientele. [3] Reasons for couples to travel to another country for ARTs are varied and include: the required services are not legal or available in their home country; they are not eligible for treatment in their home country; the efficacy of treatment is limited in their home country, or, the services in their home country have prohibitively long waiting lists or high costs [1]. The particular combination of reasons and the treatment sought will depend on the exact home country from which the person is traveling, along with the specific demographic characteristics and needs of the person desiring a child. Generally, the need to travel for ART is a combination of legal restrictions forcing people out of their home countries and attractive services drawing patients to foreign countries to access reproductive services [5].

When the reproductive tourist is from a high income country (HIC), and the provider nation is a low or middle income country (LMIC), like India, the opportunity for a host of ethical transgressions arises. This is particularly true when maternal surrogacy is involved, as it most blatantly abuts issues of female autonomy and reproductive rights [6]. It is therefore interesting to consider the nature and extent to which source countries may seek to control international ART-seeking behaviours, either through legislation or other, non-official means.

To that end, we undertook a literature review to ascertain the laws and policies of selected HICs, with respect to the disposition of their citizens seeking ARTs internationally, and with particular sensitivity to the issues arising from the seeking of services in an LMIC, most predominantly India.

\section{MATERIALS AND METHODS}

We performed a literature search of the PubMed and Google Scholar online databases, targeting selected nation names along with the following search terms and their abbreviations, grammatical and spelling variations: in vitro fertilization, assisted reproduction, artificial reproduction, reproductive tourism, cross-border reproductive care, policies, law, immigration, preimplantation genetic diagnosis, gamete donation. Abstracts were scanned for relevance to our study; and accepted papers' reference lists were further examined for additional hits. A parallel grey literature search was completed by searching the same terms on the Google search engine, selecting relevant hits by qualitatively scanning the titles of search results. 
A relevant source or paper was defined as one that described the laws and policies regarding, first, assisted reproduction in the country of interest, and, second, the procedure for repatriation of a child born via ART outside of the parents' country.

For the purposes of this study, a law or legislation is a dictate put forth by a governmental legislative body, enshrined in that country's legal code by virtue of a parliamentary (or equivalent) act. A regulation is a directive encoded through official procedure, flowing from the dictates of legislation, though not necessarily explicitly stated by the legislative body. And a policy is the standard or accepted course of action, not necessarily enshrined as either regulation or law.

The nations selected for examination were the five English-speaking OECD nations, excluding so-called micro-nations and city states, such as Singapore. They were: Canada, the USA, Australia, the United Kingdom, and New Zealand. The state of Israel was also included, since that country is anecdotally known for its embracing of new ARTs and reproductive tourism [7]. The Anglo-Saxon nations were chosen for three reasons: their anecdotally high representation amongst service seekers in Indian fertility clinics, as observed by the principal investigator; the fact that their official governmental documents would be publicly available in English; and because their shared parliamentary or congressional legislative systems provide for a common lexicon.

\section{RESULTS AND DISCUSSION}

From a total of 16 documents, mostly freely available government documents, a legislative framework for our six selected nations was prepared, with respect to ART and the legal disposition of children born abroad via ART. Results are summarized in Table 1, which describes each country's position on PGD testing, maternal surrogacy, and general social positions, such as same-sex parenting. In Table 2 are summarized each nation's policies regarding the procedures and limitations in repatriating children born abroad via ART. 
Table 1. Summary of ART, PGD, surrogacy, gamete donation, and social limitation regulations in selected nations. Blank cells indicate that no information was found relating to that issue

\begin{tabular}{|c|c|c|c|c|c|c|}
\hline & Australia & Canada & Israel & New Zealand & $\begin{array}{l}\text { United } \\
\text { Kingdom }\end{array}$ & $\begin{array}{l}\text { United States of } \\
\text { America }\end{array}$ \\
\hline ART regulated & Yes & Yes [8] & No [9] & Yes & Yes [10] & No \\
\hline Regulator & $\begin{array}{l}\text { Reproductive } \\
\text { Technology } \\
\text { Accreditation } \\
\text { Committee (RTAC) } \\
\text { [11] }\end{array}$ & $\begin{array}{l}\text { Assisted } \\
\text { Human } \\
\text { Reproduction } \\
\text { Canada Act } \\
{[8]}\end{array}$ & None [9] & $\begin{array}{l}\text { Human } \\
\text { Assisted } \\
\text { Reproductive } \\
\text { Technology } \\
\text { (HART) }\end{array}$ & $\begin{array}{l}\text { Human } \\
\text { Fertility and } \\
\text { Embryology } \\
\text { Act (HFEA) } \\
\text { [10] }\end{array}$ & None federally \\
\hline $\begin{array}{l}\text { PGD Testing } \\
\text { Regulations }\end{array}$ & Yes [11] & Yes [8] & Yes [12] [13] & Yes [14] & Yes [15] & No \\
\hline $\begin{array}{l}\text { Sex Selection for } \\
\text { social reasons }\end{array}$ & Prohibited [11] & Prohibited [8] & $\begin{array}{l}\text { Legal in certain } \\
\text { circumstances } \\
\text { [13] }\end{array}$ & Prohibited [14] & Prohibited [15] & $\begin{array}{l}\text { Acceptable, } \\
\text { depending on } \\
\text { medical reason; } \\
\text { discouraged for } \\
\text { sex selection }[16]\end{array}$ \\
\hline $\begin{array}{l}\text { To prevent the } \\
\text { transmission of a } \\
\text { genetic disease or } \\
\text { disorder }\end{array}$ & Permitted [11] & Permitted [8] & Permitted [12] & Permitted [14] & Permitted [15] & Permitted [16] \\
\hline $\begin{array}{l}\text { Maternal } \\
\text { surrogacy } \\
\text { available }\end{array}$ & Yes [17] & Yes [8] & Yes [9] & Yes [14] & Yes [10] & Yes \\
\hline $\begin{array}{l}\text { Commercial } \\
\text { Surrogacy }\end{array}$ & Illegal [17] & Illegal [8] & $\begin{array}{l}\text { Extensive } \\
\text { expense } \\
\text { reimbursement } \\
\text { [9] }\end{array}$ & Illegal [14] & Illegal [10] & Vary by clinic [18] \\
\hline $\begin{array}{l}\text { Non-commercial } \\
\text { surrogacy }\end{array}$ & Varies by state [17] & Legal [8] & Legal [9] & Legal [14] & Legal [10] & Vary by clinic [18] \\
\hline $\begin{array}{l}\text { Human Gamete } \\
\text { and Embryo } \\
\text { Donations }\end{array}$ & Yes [11] & Yes [8] & Yes [19] & Yes [14] & Yes (17) & Yes [20] \\
\hline
\end{tabular}




\begin{tabular}{|c|c|c|c|c|c|c|}
\hline $\begin{array}{l}\text { Monetary } \\
\text { Compensation }\end{array}$ & Prohibited [11] & Prohibited [8] & $\begin{array}{l}\text { Legal, amount } \\
\text { determined by } \\
\text { the Health } \\
\text { Ministry [19] }\end{array}$ & Prohibited [14] & Permitted (17) & Permitted [20] \\
\hline $\begin{array}{l}\text { Other criteria for } \\
\text { gamete donation }\end{array}$ & $\begin{array}{l}\text { Anonymous or } \\
\text { unknown donations } \\
{[11]}\end{array}$ & --- & $\begin{array}{l}\text { Women ages } \\
18-32[19]\end{array}$ & --- & --- & --- \\
\hline $\begin{array}{l}\text { Social } \\
\text { Limitations }\end{array}$ & Yes [11] & --- & Yes [9] & --- & No [15] & --- \\
\hline $\begin{array}{l}\text { Homosexual } \\
\text { Partners }\end{array}$ & $\begin{array}{l}\text { Available, if the } \\
\text { women in the } \\
\text { relationship are } \\
\text { infertile [11] }\end{array}$ & --- & Unavailable [9] & --- & Available [15] & --- \\
\hline $\begin{array}{l}\text { Single } \\
\text { woman/man }\end{array}$ & $\begin{array}{l}\text { Available, if woman } \\
\text { is infertile [11] }\end{array}$ & --- & Unavailable [9] & --- & Available [15] & --- \\
\hline
\end{tabular}


Table 2. Summary of immigration regulations, policies and/or procedures concerning repatriation of children born abroad from ART. Blank cells indicate that no information was found relating to that issue

\begin{tabular}{|c|c|c|c|c|c|c|}
\hline & Australia & Canada & Israel & New Zealand & $\begin{array}{l}\text { United } \\
\text { Kingdom }\end{array}$ & $\begin{array}{l}\text { United States } \\
\text { of America }\end{array}$ \\
\hline \multicolumn{7}{|c|}{ 1. Genetic Relationship between the child and at least one of the intended parents } \\
\hline $\begin{array}{l}\text { Parental status at } \\
\text { child's birth }\end{array}$ & --- & Legal Parent [21] & --- & $\begin{array}{l}\text { Not considered } \\
\text { legal parents; } \\
\text { parents must file } \\
\text { for an adoption } \\
\text { order [22] }\end{array}$ & $\begin{array}{l}\text { No } \\
\text { guarantee } \\
\text { that } \\
\text { intended } \\
\text { parents are } \\
\text { the legal } \\
\text { parents; by } \\
\text { default, the } \\
\text { surrogate } \\
\text { and her } \\
\text { husband } \\
\text { are } \\
\text { considered } \\
\text { legal } \\
\text { parents } \\
\text { (19) }\end{array}$ & \\
\hline $\begin{array}{l}\text { Child's } \\
\text { citizenship at } \\
\text { birth }\end{array}$ & $\begin{array}{l}\text { Can apply for } \\
\text { Australian citizenship } \\
\text { by descent [23] }\end{array}$ & $\begin{array}{l}\text { Can apply for } \\
\text { Canadian citizenship } \\
\text { by descent }[21]\end{array}$ & --- & $\begin{array}{l}\text { Not eligible to } \\
\text { claim citizenship } \\
\text { by descent,; can } \\
\text { claim citizenship } \\
\text { through adoption } \\
\text { [22] }\end{array}$ & & US citizen [24] \\
\hline \multicolumn{7}{|c|}{ 2. When there is no genetic relationship between the child and intended parents } \\
\hline & & $\begin{array}{l}\text { 1.Inter-country } \\
\text { adoption } \\
\text { When adoption is not }\end{array}$ & & & $\begin{array}{l}\text { Cannot } \\
\text { obtain } \\
\text { parental }\end{array}$ & $\begin{array}{l}\text { Intended } \\
\text { parents can file } \\
\text { for Consular }\end{array}$ \\
\hline $\begin{array}{l}\text { Options } \\
\text { Available }\end{array}$ & & $\begin{array}{l}\text { possible: } \\
\text { 2. Submit a written }\end{array}$ & & & order [20] & $\begin{array}{l}\text { Report of Birth } \\
\text { Abroad (CRBA) }\end{array}$ \\
\hline
\end{tabular}




\section{Required Documents}

From intended Completed Australian parents citizenship by descent DNA tests confirming parentage; attestation from lawyer in birth country; certificate from hospital where birth took place; proof of payment of all medical and hospital bills [23]

From the Surrogate

Letter of no objection

(21) application form;

confirmation from the

foreign jurisdiction or expertise at the visa office.

\section{OR}

3. Obtain a temporary resident permit card for the child, an application for humanitarian and compassionate

permanent resident and a citizenship or grant under

"Citizenship Act" [21]

Birth Certificate with intended parents'

names;

proof of payment of

hospital bills; contract between intended

parents and lab [21]
Contract agreement between surrogate and intended parents [21] of an American

Citizen and for a

US passport [24]

\section{New Zealand Family Court adoption order; and approval of a social worker [22]}

Consent; details

of surrogacy arrangement; identity and

information of any gamete donor(s) [22]

\begin{tabular}{|c|c|}
\hline $\begin{array}{l}\text { Must obtain } \\
\text { parental } \\
\text { order [20] }\end{array}$ & $\begin{array}{l}\text { Evidence of: } \\
\text { child's } \\
\text { conception and } \\
\text { birth; identity } \\
\text { and citizenship } \\
\text { of intended } \\
\text { parents; } \\
\text { physical } \\
\text { presence in the } \\
\text { USA; DNA tests } \\
\text { confirming } \\
\text { parentage [24] }\end{array}$ \\
\hline $\begin{array}{l}\text { Surrogate } \\
\text { and legal } \\
\text { father must } \\
\text { give } \\
\text { consent }\end{array}$ & $\begin{array}{l}\text { If surrogate is } \\
\text { the genetic } \\
\text { mother, she } \\
\text { must provide } \\
\text { consent [24] }\end{array}$ \\
\hline
\end{tabular}


The heterogeneity of the ART global regulation landscape has been one of the complicating factors in the evolution of the global ART industry. In countries like the USA, jurisdictional disputes between federal and state-level regulators are one of the causes of a lack of a national ART strategy [25]. As ARTs involve many of the more ethically challenging issues of our day --including women's health, abortion, the evolving definition of family, sex selection, and genetic manipulation-the extent to which federal law in a liberal democracy reflects the values of a given population must be considered. Thus, it can be argued that the expression of such value via federal regulation also represents the culmination of a national dialogue on those issues; and, relatedly, absence of such regulation might be indicative of either a deep heterogeneity in public opinion, or of a comfort with the ability of private industry to selfregulate on these matters.

The extent to which a federal government and the ART industry partner to define regulations is one of the ethical issues we identified in an earlier paper [6], having more to do with crossborder maternal surrogacy. The question arises, then, to what extent does such regulation reflect the true value of the population, versus the extent to which it serves the commercial needs of the industry. Of particular note is the observation that commercial surrogacy is either illegal or heavily restricted in all of the examined nations. Yet, in at least three countries (Australia, Canada, and the USA) there exists an established legal process $[23,24,21]$ for the repatriation of a child produced abroad via commercial surrogacy, without any penalty for the domestic regulation that that reproduction seemingly violated.

In our earlier papers $[26,6]$ that examined the various ethical dimensions of the international assisted reproduction industry, we determined that regulatory expressions are, to an extent, both attempts to assuage ethical concerns and simultaneously reflections of society's current ethical condition. While the present paper does not portend to deeply explore ethical considerations, it is important to note that we have only described laws, regulations, and policies as they are written, and not necessarily as they are interpreted or practiced. A society's ethical framework manifests through both its articulation and application of such rules, not just through its overt phraseology. An example of this oversight is the Assisted Human Reproduction Act in Canada, elements of which were successfully challenged in a Supreme Court Case in 2010 [27]. The law remains on the books, but is interpreted selectively, according to the specifics of the court challenge.

There are, of course, many other examples of domestic laws for which governments will not prosecute their citizens if violated abroad in a jurisdiction in which the act is not a crime; recreational substance use, for example. Notable exceptions are those concerning sex tourism, as in the US PROTECT Act of 2003 [28], which allows for the legal prosecution of American citizens who purchase the sexual services of minors outside of American soil. Commercial surrogacy tourism, especially when it involves surrogates in LMICs, has been compared to both organ tourism and sex tourism, in terms of its reliance on the paid physical participation of a third party, often at the expense of their own health or safety [29]. Inasmuch as surrogacy may involve the exploitation of a vulnerable woman, as is one point of view [30], it may warrant similar consideration for the extension of prosecution beyond a user's home nation. Clearly, commercial surrogacy is a service whose ethical parameters are troubling to many, and thus arguably deserving of a government-overseen regulatory framework, at the very least.

Across all of the examined countries for which a regulator was identified, policies concerning surrogacy sought to distinguish between the practical and ethical impacts between traditional and gestational surrogacy. The former involves the surrogate's ova, while the latter involves 
the gestation by the surrogate of an embryo created from another woman's ovum. This is because two separate definitions of motherhood are thus disentangled: via the process of birthing versus via a genetic relationship. All nations also sought to distinguish between paid and unpaid surrogacy, with most choosing to criminalize the former but not the latter. One of the results of both of these decisions is the rapid growth of a gestational commercial surrogacy market in nations that have not taken these regulatory steps, India prime among them. The existence of global reproductive tourism, then, is due not just to an economic gradient that drives HIC clients to less expensive LMIC providers, but perhaps also due to a regulatory gradient, which drives clientele from more regulated to less regulated jurisdictions.

As India's domestic regulations evolve, it is interesting to see how their decisions will affect the global industry, given how that nation's limited restrictions have helped to grow their industry. While India has not yet made new law on the matter, their most recent draft bill [31] indicates that their focus is on clinical matters, and not on the restriction or limitation on the scope or complement of service provision, a tack which is unlikely to diminish the flow of foreign clientele to Indian ART clinics. Activist groups accuse the government of structuring its bill to best service ART commercial interests, and not sufficiently protecting Indian surrogates or properly reflecting the true sentiment or values of the electorate [32].

The provision of PGD is a new service in Indian clinics, but one that is fast being adopted and advertised [3]. It is, however, prohibited in almost all of the HICs examined, especially with respect to its application for sex selection. However, HIC regulators are aware of PGD's strong potential for disease screening. The challenge, of course, is to balance PGD's undeniable medical value against its potential for quasi-eugenic social engineering. To make this distinction in law is somewhat meaningless without the resources and wherewithal to both monitor and enforce the technology's application and disposition in actual labs.

We included PGD as a service whose regulatory culture is of particular interest to gauge whether existing policy frameworks are sensitive to technologies that are, in some ways, still on the horizon. The fact that testing regulations are present in all examined nations, save Israel, may indicate an ethical concern. Despite the technique's comparative novelty, at least relative to its sister technologies IVF and ICSI (intracytoplasmic sperm injection), it is of sufficient ethical interest to warrant specific regulation. Some might view the existence of such regulations as a sign of a government's evolving rapid responsiveness to technologies that are as yet not fully in the public lay lexicon.

More countries, both established and emerging economies, are formulating ART regulations. Forces shaping new policy are not merely the values and desires of the domestic population, but also the agents of a global, growing industry. What must not be lost in the tension between these forces is the ultimate need for the preservation of the rights, health, and safety of all actors: children born via ART, potential parents, gamete donors, surrogate mothers, and service providers. Future research in this topic should include a description of the patterns and demographics of individuals traveling internationally to seek ART services, along with the extent to which regulations have influenced their choices.

\section{CONCLUSION}

Reproductive tourism is an expanding international industry that is complicated by heterogeneous regulatory patterns in nations most likely to be providing clients seeking reproductive services abroad. 


\section{CONSENT}

All authors declare that since no human subjects were involved in this study, no consent was required.

\section{ETHICAL APPROVAL}

All authors declare that since no subjects, human or otherwise, were involved in this study, no institutional ethics approval was required.

\section{COMPETING INTERESTS}

Authors have declared that no competing interests exist.

\section{REFERENCES}

1. Ferraretti AP, Pennings G, Gianaroli L, Natali F, Magli MC. Cross-border reproductive care: a phenomenon expressing the controversial aspects of reproductive technologies. Reprod Biomed Online. 2010;20(2):261-266.

2. Brenhouse H. India's Rent-a-Womb Industry Faces New Restrictions. Time Magazine. 2010 June 5.

3. Deonandan $\mathrm{R}$, Loncar $\mathrm{M}$, Rahman $\mathrm{P}$, Omar $\mathrm{S}$. Measuring reproductive tourism through an analysis of Indian ART clinic websites. International Journal of General Medicine. 2012;5:763-773.

4. Fontanella-Khan A. India, the Rent-a-Womb Capital of the World: the country's booming 1market for surrogacy. Slate Magazine; 2010 Aug 23.

5. Nygren K, Adamson D, Zegers-Hochschild F, de Mouzon J, International Committee Monitoring Assisted Reprod. Cross-border fertility care--International Committee Monitoring Assisted Reproductive Technologies global survey: 2006 data and estimates. Fertil Steril. 2010;94(1):e4-e10.

6. Deonandan R, Green S, van Beinum A. Ethical concerns for maternal surrogacy and reproductive tourism. Journal of Medical Ethics. 2012;38:742-745.

7. Staff. elVF News. [Online]; 2012. [cited 201212 25. Available from: http://eivf.net/blog/2012/05/21/israel-promotes-fertility-via-assisted-reproduction/.

8. Government of Canada. Government of Canada. [Online].; 2011 [cited 20121225. Available from: http://www.ahrc-pac.gc.ca/v2/faq/ahraFAQ-lspaFAQ-eng.php.

9. Lipkin N, Samama E. Isha L'Isha. [Online]; 2010. [cited 201212 25. Available from: http://www.isha.org.il/upload/file/surrogacy_Eng00\%5B1\%5D.pdf.

10. Government of Canada. Health Canada. [Online]; 2004. [cited 201212 25. Available from: http://www.hc-sc.gc.ca/hl-vs/reprod/hc-sc/general/international-eng.php.

11. Reproductive Technology Council. Department of Health. [Online].; 2012 [cited 2012 12 25. Available from: http://www.rtc.org.au/contact/index.cfm.

12. Law Library of Congress Israel. Reproduction and Abortion: Law and Policy. [Online]; 2012. [cited 201212 25. Available from: http://www.loc.gov/law/help/israel 2012007460 IL FINAL.pd.

13. Zafran R. Non-Medical Sex Selection by Pre-implantation Genetic Diagnosis: Reflections on Israeli Law and Practice. North Carolina Journal of Law \& Technology. 2008;9(2):187-218. 
14. New Zealand Legislation. Parliamentary Counsel Office. [Online]; 2004. [cited 201212 25.

Available from: http://www.legislation.govt.nz/act/public/2004/0092/latest/whole.html.

15. Human Fertilization and Embryology Authority. The HFE Act (and other legislation). [Online]; 2012. [cited 201212 25. Available from: http://www.hfea.gov.uk/134.html.

16. Genetics and Public Policy Center. Reproductive Genetic Testing: a regulatory patchwork. [Online]. [cited $2012 \quad 12 \quad 25 . \quad$ Available from: http://www.dnapolicy.org/policy.international.php?action=detail\&laws id=63.

17. National Health and Medical Research Council. Ethical guidelines on the use of assisted reproductive technology in clinical practice and research. [Online].; 2007 [cited $2012 \quad 12 \quad 25.2$ Available from: http://www.nhmrc.gov.au/ files nhmrc/publications/attachments/e78.pdf.

18. National Center for Chronic Disease Prevention and Health Promotion. Assisted Reproductive Technology Success Rates National Summary and Fertility Reports. [Online]; 2009. [cited $2012 \quad 12 \quad 25 . \quad$ Available from: http://www.cdc.gov/art/ART2009/PDF/ART 2009 Full.pdf.

19. Gruenbaum FB, Pinchover SZ, Lunenfeld E, Jotkowitz A. Ovum donation: examining the new Israeli Law. European Journal of Obstetrics \& Gynecology and Reproductive Biology. 2011;159:40-42.

20. Knowles LP. Stem Cell Network. [Online]. [cited 201212 25. Available from: http://www.stemcellnetwork.ca/uploads/File/whitepapers/Commercialization-and-StemCell-Research.pdf.

21. Citizenship and Immigration Canada. Operation Bullet 381. [Online].; 2012 [cited 2012 $12 \quad 25 . \quad$ Available from: http://www.cic.gc.ca/english/resources/manuals/bulletins/2012/ob381.asp.

22. Internal affairs, child, youth and family and immigration New Zealand. International Surrogacy Information Sheet. [Online]. [cited 201212 25. Available from: http://www.acart.health.govt.nz/moh.nst/pagescm/22/\$File/international-surrogacyfactsheet.pdf.

23. Australia High Commission India. Child born through surrogacy arrangements. [Online]. [cited 20121225.

Available from: http://www.india.embassy.gov.au/ndli/vm surrogacy.html.

24. US. Department of State. Important Infromation for U.S Citizens Considering the Use of Assisted Reproductive Technology (ART) Abroad. [Online]. [cited 20121225. Available from: http://travel.state.gov/law/citizenship/citizenship_5177.html.

25. Riggan K. The Center for Bioethics and Human Dignity. [Online]; 2011. [cited 201212 25. Available from: http://cbhd.org/content/regulation-or-lack-thereof-assistedreproductive-technologies-us-and-abroad.

26. Deonandan R. An Introduction to the ethics of reproductive tourism. In Labonte R, Runnels V, Packer C, Deonandan R, editors. Traveling Well: Essays in Medical Tourism. Ottawa: University of Ottawa; 2013;151-177.

27. Deonandan R, Rahman T. Implications and reflections on the 2010 Supreme Court ruling on Canada's AHR Act. International Journal of Women's Health. 2011;3:405408.

28. United States Government. US Government Printing Office. [Online]. [cited 201212 25. Available from: http://www.gpo.gov/fdsys/pkg/PLAW-108publ21/html/PLAW108publ21.htm.

29. Deonandan R. The Huffington Post. [Online]; 2012. [cited 201212 25. Available from: http://www.huffingtonpost.ca/dr-raywat-deonandan/reproductivetourism b 2039343.html. 
30. Markens S. The global reproductive health market: U.S. media framings and public discourses about transnational surrogacy. Soc Sci Med. 2012;74(11):1745-1753.

31. Ministry of Health \& Family Welfare, Government of India. The Assisted Reproductive Technologies (Regulation) Bill. New Delhi; 2010.

32. Sama: Resource Group for Women and Health. The Regulation of Surrogacy in India: Questions and Complexities. [Online]; 2011. [cited 201212 25. Available from: http://samawomenshealth.wordpress.com/2011/04/23/the-regulation-of-surrogacy-inindia-questions-and-complexities/.

(C) 2014 Deonandan and Bente; This is an Open Access article distributed under the terms of the Creative Commons Attribution License (http://creativecommons.org/licenses/by/3.0), which permits unrestricted use, distribution, and reproduction in any medium, provided the original work is properly cited.

Peer-review history:

The peer review history for this paper can be accessed here:

http://www.sciencedomain.org/review-history.php?iid=215\&id=12\&aid=2015 